\section{Management-related information on Spanish university library Web pages}

\author{
Ana R. Pacios
}

\section{The author}

Ana R. Pacios is in the Library Science and Documentation Department, Carlos III University, Madrid, Spain.

\section{Keywords}

Management information, University libraries, Worldwide web, Spain

\section{Abstract}

A typological analysis of the management-related documents that Spanish university libraries show on their Web sites is provided. The paper discusses about the structure and contents of the Web pages; provides some analysis on the location of the documents in the pages; and presents a view of document changes after 1 year, taking into account their presence and currency.

\section{Electronic access}

The Emerald Research Register for this journal is available at http://www.emeraldinsight.com/researchregister

The current issue and full text archive of this journal is available at

http://www.emeraldinsight.com/0264-0473.htm

\section{Introduction}

Like other public and private institutions, university libraries are starting to offer management information about themselves to their users through their Web site - an efficient dissemination tool that they all have. Besides providing information, managementrelated documents contribute greatly to creating a good image for the library service, and therefore they should be present in all library marketing plans.

This paper follows the line of others that have analysed the different aspects of the contents, form, structure and functionality of the information offered by the university libraries on their Web pages. There have been many studies, both in Spain and abroad, in the last few years. The purpose of Borrego's study (Borrego, 2000), which includes a complete bibliography, is to explain what information Spanish university libraries (SULs) give about their own management. We analyse the types of documents with respect to their functions, instruments and management techniques. A second objective is to see how these documents have changed with time, and to what extent they are reviewed and updated.

Libraries normally classify the information they offer on their Web pages into four groups: information about the library itself, information for reference purposes, information for research purposes, and information for educational purposes (Cohen and Still, 1999, p.278). A library's management-related information would fit into the first group, as the relevant documents give information about the library. However, it could clearly be useful also for other purposes, different from what it was originally conceived for. Having this information in the library's Web site would be useful for both the professionals working in libraries and the teachers of library science, in the following two ways.

(1) Research. We must remember that this information is essential to do any benchmarking, a management technique nowadays unavoidable to plan, organise or evaluate a library. Easy access to this information on the Web allows librarians, for example, to select centres that share a particular feature in order to investigate how or why that happens, or even to visit them and learn the details on site. It is not 
just useful for librarians who need to know the best practices, but also to teachers of library and information sciences whose research task, specifically their hard field-work, has been eased by the accessibility to this type of information due to the World Wide Web (WWW). This paper is an example of it; if we had had to contact each library to obtain all the necessary documents, the exercise would have been both timeconsuming and expensive.

(2) Education. Although it is not of the same type as the education addressed to users to help them optimise and get the most out of the information resources, as a library management educator, the author stress that the management documents available in the Web pages are most useful for the librarians-to-be. Until recently we had, at most, some management-related reports, statistics and little more. We had to rely on the experiences that management-specialised librarians would share with us in conferences, magazines, seminars, etc. In addition to that, we have strategic plans, quality plans, managerial staff, rules and procedures manuals, etc., just to give few examples. Thus, students can see management theory put into practice, with real-life examples of known libraries or even of their own library.

\section{Methodology}

To prepare this paper, we visited the Web sites of the SULs included in the Consejo Superior de Investigaciones Cientificas (CSIC) directory. From its Web page[1] one can access each one of the Spanish universities' Web pages. There are 60 libraries, all public but for a few exceptions. We missed only two of them, because we could not access their Web pages: one (Internacional de Andalucía) because it was not working, and the other (Cardenal Herrera) because it was in the process of being built. The focus of the consultation was on the library's homepage, i.e. the page that contains information about the library itself and that one can reach by surfing from the university's homepage. We did not consult Web pages of other libraries, such as campus, area, centre, or institute libraries.

Once we had collected the appropriate management-related documents, we did an analysis of both form and contents, which shows the management situation of the libraries. There is significant variation among the libraries. However, let us clarify that these results are not final, as the information on the Web pages is very dynamic and can change quickly; therefore, we cannot consider any situation as unchangeable. This is precisely why we wanted to know how these documents and their contents have changed with time, and tried by means of two reviews: we completed the first one in September 2001; the second one, a year after, in December 2002. During the course of this research work, we saw that there had been some significant changes; for example, in the number and order of the libraries in the directory we chose to use; there were changes even in both the structure and contents of some Web sites. On the other hand, this situation is logical, as Web sites must have an open structure and be continuously reviewed and updated. We saw these elements during the course of this research.

As the goal was to carry out an analysis of both form and contents that would show the current situation of the "management-related information" provided by SULs, we did not consider some quantitative and qualitative aspects of the libraries, such as the number of students, available human resources, or the size of the collection. The stress was on what documents are chosen by the library to inform its users about how it manages itself; for example, what are its goals for the next years, what indicators it is using to evaluate itself, what its organisation structure is like, etc. The purpose is not to establish a ranking or, even less so, to suggest that some libraries are working better than others, because not having that information on a library's Web site does not mean it may not be using the most appropriate management techniques given its situation or organisation. On the other hand, we know that some libraries actually have some of these documents, but do not make them available on their Web site.

\section{Document typology}

We have considered all management-related documents as documents resulting from the execution of management functions (planning, organisation, leadership, and control), and within them the functions that relate to the management and optimisation of 
the library resources (human, financial, equipment, and collection). We also considered the information about the different bodies that participate in management; and also some documents that we consider necessary to provide quality services, such as suggestion forms, questionnaires and service charts. We did not start with a pre-established document typology; instead, we added documents to the table as we found in a Web page. Generally, we identified each document by the name of the link that gives access. Thus, results are normally for libraries whose Web page headings are as they appear in Table I; however, we have also included some documents that, although having no link of their own, we found in other information blocks.

Documents relating to the management of a SUL that may be accessed from its Web site,

Table I SULs information about their own management offered by their Web pages and one-year change in the presence of management-related document types

\begin{tabular}{|c|c|c|}
\hline Document typology & $\begin{array}{c}2001 \\
\text { (per cent) }\end{array}$ & $\begin{array}{c}2002 \\
\text { (per cent) }\end{array}$ \\
\hline Suggestions & 41.67 & 87.93 \\
\hline Service use rules & 70.69 & 82.76 \\
\hline Fees/prices & 25.86 & 60.34 \\
\hline Regulations & 48.28 & 53.45 \\
\hline Organisation structure & 31.03 & 44.83 \\
\hline Statistics & 34.48 & 36.21 \\
\hline Co-operation & 29.31 & 29.31 \\
\hline Evaluation reports & 15.52 & 20.69 \\
\hline Annual reports & 15.52 & 17.24 \\
\hline Duplicate exchange & 18.97 & 15.52 \\
\hline Projects & 12.07 & 12.07 \\
\hline Working groups/library boards & 6.90 & 10.34 \\
\hline Mission & 3.45 & 10.34 \\
\hline Plans & 10.34 & 8.62 \\
\hline Public announcements for selection & 8.62 & 5.17 \\
\hline Organisation charts & 5.17 & 5.17 \\
\hline Service chart & 1.72 & 3.45 \\
\hline Surveys & 5.17 & 3.45 \\
\hline Chart of user's rights and duties & 1.72 & 1.72 \\
\hline Awards/certifications & 1.72 & 1.72 \\
\hline Balanced scoreboard/indicators & 1.72 & 1.72 \\
\hline Procedures handbook & 5.17 & 1.72 \\
\hline Sponsors & - & 1.72 \\
\hline Staff training plan & - & 1.72 \\
\hline Financing policy journals & - & 1.72 \\
\hline Budget & - & 1.72 \\
\hline Collections management policy & - & 1.72 \\
\hline Jobs list & - & 1.72 \\
\hline
\end{tabular}

as available in December 2002, present the following typology and peculiarities, ranked by decreasing number or appearances.

\section{Suggestions (87.93 per cent)}

In line with their policy of continuously probing their users' opinion, most libraries offer a link with this name. Through this link, one can send suggestions, opinions or comments related to any library issues. Although in a less conspicuous way, 68.9 per cent have an e-mail address that may be used for that purpose; but sometimes it is hardly noticeable, as it is located at the bottom of the page. Other libraries, about 25.8 per cent, offer a better image, with links under more attractive names to send comments or suggestions, such as "Give us your opinion on the library", or "Your opinion"; they also have a questionnaire. Only three libraries offer the two options to collect the users' opinions: e-mail and an ad hoc questionnaire.

Knowledge of the users' expectations, complaints, needs and wishes is absolutely necessary to manage a quality service.

\section{Service use rules (82.76 per cent)}

Practically all SULs have this type of document. Specifically, the most often found rules relate to access, consultation, and loans, particularly the latter. Normally, loan-related documents present a similar structure: terms and conditions depending on the type of user, and incidents and penalties. Other rules regulate the use of other services, such as Acquisitions, Research Booths, Media Library, Newspaper Library, Map Library, Old Collection, and Access to the Internet.

\section{Fees/prices (60.34 per cent)}

More than half of the university libraries have a link to the prices or fees for their interlibrary loans, for the document supply centres, and terms of payment. With just one exception, they all show the REBIUN (Suls Network) prices. The Biblioteca Nacional and British Library prices are also often shown.

\section{Regulations (53.45 per cent)}

This is the basic reference set of rules that all libraries should have, and therefore we have considered it separately from the above rules. The purpose of the Regulations is to guarantee the documentary information that the university needs in order to reach its teaching, study, research, and scope goals. 
The Regulations define the library model each university wants, the services it must provide and its organisation. They are normally structured as a set of articles, with sections or chapters devoted to very different issues depending on the library's size: users, governing bodies, staff, financial resources, etc. (Herrera Morillas et al., 2001).

\section{Organisation structure (44.83 per cent)}

A significant number of libraries provide data with varying degrees of detail on their organisational structure: whether it is centralised or decentralised, its different sections, departments, etc.

\section{Statistics (36.21 per cent)}

Various SULs offer their users statistics on the users themselves, equipment, collection, opening days and hours, premises, documents, staff, budget, use of the different services, etc. They normally follow the model proposed by REBIUN to prepare its yearbook with information of practically every SUL[2]. Statistics are for the year before, but some libraries provide them for earlier years as well. Sometimes, it is possible to consult them by service point.

\section{Co-operation (29.31 per cent)}

This includes the activities and projects whose purpose is to facilitate access to bibliographic and library resources and which result from co-operation agreements with other organisations and institutions (universities, foundations, banks). They provide an image of the outside hold of the library. Most of these documents inform about the co-operation networks or consortia the library belongs to, the most frequently quoted being REBIUN. Some libraries offer information about their specific activity in the network, such as the working team to which they belong, and its goals.

\section{Evaluation reports (20.69 per cent)}

At the moment, these are the most relevant documents with respect to the management of the library, providing information of its existing situation and what it intends to do in the future. These reports are the result of the evaluation process carried out in the library for the purpose of knowing the efficacy, efficiency and use of, and satisfaction with, the services it provides and, based on that knowledge, implementing some actions to improve. These initiatives are not isolated, but are part of a series of actions aiming at improving quality at the universities. The framework is the Quality Evaluation National Plan, proposed by the Council of Universities. With different participating universities, the Plan's goal is the institutional evaluation of the whole organisation.

There are several libraries currently undergoing this process. Others have already finished it and offer various reports on their Web site in accordance with the publicity requirements of the methodology they use. The most widely used methodology is the "Catalan model", suggested by the Agency for the Quality of the University System in Catalonia, and more specifically the Evaluation Guide of Library Services. Its most outstanding feature compared with other models, such as the European model from European Foundation for Quality Management (EFQM) is the importance given to the users' opinion, as well as the stress placed on the analysis of services rather than processes.

The evaluation process has three stages, each giving rise to a different report.

(1) Self-evaluation, where an Evaluation Committee including representatives from all university and library staff groups prepares a report with the data and information collected, with the opinions and thoughts of the different agents. This very detailed report has the following sections: The library and its integration in the institution; Processes and communication, Staff resources, Facility resources, Fund resources, and Results. Of particular interest are the Strengths and weaknesses and the presentation of a series of proposals to improve the quality of the service.

(2) External evaluation, where an External Evaluation Committee, whose members are experts who do not belong to the university, analyses the above self-evaluation report, visits the library, collects evidence and opinions from the users, and writes an External Evaluation Report. This report includes the thoughts and conclusions of the Committee on design, organisation, and development of the process, and the results of the evaluated service, with an aim at estimating its quality and proposing any actions for improvement that the Committee may think fit. The contents of this report is structured as follows: 
Introduction; Analysis of the internal evaluation process; Assessment of the External Evaluation Committee; Overall evaluation: conclusions and recommendations; and Assessment of the external evaluation process.

(3) Final Evaluation Report is prepared by comparing the assessments and results of the Internal Evaluation Report (prepared by the Internal Evaluation Committee) and the External Evaluation Report (prepared by the External Evaluation Committee). The purpose of this final report is threefold: to synthesise the assessments of the other two reports, to list the strengths and weaknesses, and to identify and program proposals for improvement. It has the following sections: Introduction; Assessment of the external evaluation process; Assessment of the internal evaluation process; Strengths and weaknesses; and Actions for improvement.

We must stress the importance of this final report, because it provides an accurate idea of the situation of the library and its lines of action for the near future. The final charts of the actions for improvement, where we find information on the specific offer, its priority, accountability, deadlines, and approximate cost, are highly illustrative.

This paper takes into account the libraries that, in one way or another, provide information on their evaluation process, even if some of these libraries do not have their reports available yet.

\section{Annual reports (17.24 per cent)}

These are detailed annual management reports for all library areas, services and activities. As well as Statistics, the Annual Report is one of the most representative documents with respect to the control function. With the help of statistics, the Report deals with significant aspects of the library situation, budget and funding, staff, users, premises and facilities, the computerisation process, services, and external relations. It normally provides graphs to compare the existing situation with that of the preceding years. Some reports also include the library goals for the next year.

\section{Collection management documents}

The information provided by SULs specifically on collection management is hardly significant. Practically (15.52 per cent), they just inform about the duplicate available to facilitate the exchange with other interested institutions and libraries. Some present the duplicate bulletins in different formats. We have also found information on the management of donations, how they are processed, what to do to make one, and how to access to and use them.

There is also information about the collection, but it is clearly temporary, such as the lists of magazines subject to evaluation. We did not include this information on our table because it is very biased, as there is no criterion or any details about the process. One exception to this is the Carlos III University, which allows access to the collection's Management Policy or Program, a most interesting document that serves as a guide to all activities related to, essentially, the planning, budgeting, selection and purchasing of library materials. It is considered as a decision-making tool and means of communication within the organization. Also, it is a basic instrument to train staff members who will deal with the selection and acquisition tasks.

In relation to this section, we also found the document called "Financing Policy of Journals", from the Almería University library; it explains the procedures to request and cancel scientific magazines, and to buy back issues.

\section{Projects (12.07 per cent)}

This is the information about in-progress or already finished projects. Although some of these projects are for co-operation with other institutions and therefore we have considered them in the appropriate section, there are some libraries that inform about projects of their own. They relate to computerising collections, creating digital libraries, launching new information resources, erecting new buildings, etc.

\section{Working groups and library boards (10.34 per cent)}

Some libraries provide information about the existing working groups, thus showing their methodology and management system. These groups work at improving the services or solving the existing problems. In the case of Universidad Autónoma de Barcelona, where they are called "improvement groups", the information includes the following blocks: spotted problems, solutions, people 
responsible, implementation area or centre, result indicators, implementation date, results, and state of affairs. Occasionally a library may mention the working group to which it belongs in the university libraries network, as there are several and their members come from different universities.

With a different name - commissions - but similar goal, they exist at the Pompeu Fabra University. They are called Quality Commission, Technology Strategy Commission, and Information Resources Commission. There is information about their governing rules, functions, composition, and members.

Others provide a specific link with information relative to their main commission, i.e. the body that plans, develops and manages the university library. However, these cases are exceptional, as the library's functions are covered in all the Regulations, and therefore the information can be found there.

\section{Mission (10.34 per cent)}

We understand mission as the explicit declaration that defines in broad terms the main, distinctive purpose of the library, and which is generally used within the framework of a strategic approach (Corrall, 2000, p.79). Although many libraries define their functions, aim, objectives or goals more or less explicitly, sometimes taking this from their own Regulations or by reference to the University Statute, just five of them have a definition of mission as above. As the definition of mission must be reviewed and updated from time to time, one of such libraries provides the date of the last review.

\section{Plans (8.62 per cent)}

We have come across some plans that could be classed as strategic plans, with lines of actions for periods between three and five years. They include the library goals. But for one exception, they all are very synthetic. The fairly detailed plan of Universitat Politécnica de Catalunya includes sections devoted to mission, vision, values, users and their needs, goals, action areas, and indicators, for each action line. The highly specific Environmental Plan of the libraries of Universitat Politécnica de Catalunya is particularly interesting.

\section{Public announcements for selection (5.17 per cent)}

They are all for grants to collaborate with the library. These are the only documents we have found related to the management-recruiting and selection-of human resources. Although this information is clearly temporary, we have decided to include it here, as interns form a numerous group and are highly influential in some libraries. These announcements normally give the number of openings, their length, pay, requirements, evaluation criteria and deadlines for applications.

\section{Organisation charts (5.17 per cent)}

Although many libraries provide some detail of their organisational structure, just two of them do it graphically by means of an organisation chart. This, as well as showing the existing organisation units, allows us to see their connections and hierarchical links.

\section{Service chart ( 3.45 per cent)}

This document informs the users about the conditions and quality commitments on which the services are provided, as well as the user rights in relation to them. The Chart is not a "tablet of stone"; it is the formal service level agreement between a library service and its clients. This agreement is an expression of the current situation and the current level of service. In Spain, the Public Administration has fostered among the State General Administration bodies, its public organisations and entities and common services, the creation of this type of document, by publishing a Royal Decree (1259/1999) that regulates service charts and quality awards in the State General Administration[3]. Its structure and contents must include, without limitation, the following: a list of services provided, basic information about the institution, opening hours, quality commitments, access to the complaint and suggestion system, and quality indicators. The only service chart that actually contains all these elements is the Politécnica de Catalunya library's.

\section{Surveys (3.45 per cent)}

Within the framework of their quality control evaluation processes, some libraries invite the users to answer some surveys to evaluate their satisfaction with, and use of, the services. The existing surveys are addressed to both teachers and students. The Universitat Politécnica also provides information on the used methodology, statistical treatment of data, conclusions, and a comparison of the surveys carried out during three academic years. This information was consulted in September 2001; in September 2002 it was no longer available. 


\section{Chart of user's rights and duties (1.72 per cent)}

The Pompeu Fabra University is the only one that has this document, in a form similar to a service chart, reflecting the "mutual commitment between the library and its users". Its structure and contents are divided into four sections: space, information resources, services, and staff.

\section{Management recognition (awards and certifications) ( 1.72 per cent)}

Just Universidad Autónoma de Barcelona provides a digitised copy of its official certification (Quality Certification) and information related to all the certification process. It is the result of the implementation of a quality system based on the ISO-9002 standard. We stress the interest of this information, as a practical example of the implementation of an ISO standard to a library service. It was available in September 2001; no longer available. Also the university library of the Balearic Islands was exhibiting, on its Web page on July 2002, the logo of an award it received in recognition of its management.

\section{Balanced scoreboard or indicators used in the evaluation of the service (1.72 per cent)}

The scoreboard constitutes a management control instrument. According to professors Kaplan and Norton, it is characterised because it seeks to "measure the result in organising the future". To indicators measuring actions, it adds financial and non-financial indicators of the key factors, deriving from the organisation's vision and strategy, that will influence results in the future. It focuses on converting the organisation's vision and strategy into strategic objectives and indicators. To do this, the authors' approach contemplates an organisation from four different perspectives: financial, client, internal operative processes, and learning and growth (Kaplan and Norton, 2000). Following this model, the Pompeu Fabra University presents a scoreboard with four large divisions: vision, key success factors, indicators, and person responsible for providing the information.

Further to these last three documentary types, with their own link, of which we have just found one case of each, there are five more that follow the same line: a library Jobs List (La Rioja), a Procedures Handbook (Santiago de Compostela), information on
Sponsors (Cantabria), a Staff Training Plan (Balearic Islands), and the library's Annual Budget (Cantabria). With respect to the Procedures Handbook, although we only found one in September 2002, in September 2001 we saw that there were other cases. The Malaga and Rey Juan Carlos libraries' Web pages had links to respective handbooks: the former to Interlibrary Loans; the latter to Internal Loans and Acquisitions. Both handbooks gave details of the library's operations and "way of doing things" in those services. Also, they were providing statistics and other additional information about the services. Libraries seldom allow access to this type of internal documents, which are associated with the organising function, and are generally restricted to the library's intranet to be consulted by its librarians. In fact, we have found some library's homepage with a link to the intranet where there are headings referring to procedure manuals, but access is restricted to library staff. In other cases, there is a link called "Internal working documents", but is not always accessible by all users, just to librarians. The University of Zaragoza is an example of this.

One type of document that we found, but did not enter in Table I is the library layout. These documents are the only ones disclosing information on space management. There are not many, and some are even just partial, as they may only cover some of the sites of the library. Maps are normally shown by floor, with services indicated. Another type of map that we have found in the Web pages shows the location of the library within the university campus.

Finally, although actually it is not a document related to management, some libraries have an information block that contains different works presented by their staff in workshops, conferences, etc. They do it under the heading Professional Publications and Working Documents. It is worth remembering some of these documents as they logically deal with experiences in management techniques applied to the library.

The Appendix lists some representative examples of the types of documents analysed in the study.

\section{Location}

Location of the documents in the Web pages varies considerably. There are two different situations. 
(1) Libraries that group most of these documents into one information block. These are also the libraries that make available the highest number of management documents. They normally do it through a link in their homepage using a name that encompasses all the information. The headings used are: "About the library", "The library", "Information", "General information", "Library information", "University library", "Organisation", and "Library documents". The most common documents included are the Rules, Regulations, Suggestions, and Statistics and these are found in second and third level. Some libraries leave Co-operation outside of these blocks.

(2) Libraries whose management information is dispersed under different headings, not grouped together. This is a fairly generalised situation and coincides with the libraries that offer the least documents. The level where they are found changes a great deal, from the second upward, even the sixth level. Locating them was difficult when there was no Web page index or map. A representative example are the Rules. Almost all libraries have rules in their Web page in relation to the use of some service, but they do not always group them under a common heading; in some, the rules are accessed through the link for the relevant service.

\section{One-year variation in the presence of the document types}

The second goal of our work was to see how the pages had been updated, improved, and their management-related information extended, during the course of one year. As mentioned earlier, we completed the first review of the pages in September 2001, and the second in December 2002. The latter showed that 93 per cent of the Web pages had undergone some change, which was also reflected in the date at the foot of each page. Thus we say that, after one year, libraries have extended and improved the information they offer about their own management. Table I shows that percentages have gone up for almost every type of document. Nonetheless, it is difficult, sometimes even impossible, to make an overall assessment of most libraries using only the information they publish on their Web pages.

Page updating was apparent in yearly documents, such as year reports and statistics. Some strategic plans whose term had elapsed have been removed from the page, but have not been replaced by other plans, as would be expected to be consistent. On the other hand, there are also some pages that have an update date, but whose links have had no contents whatsoever for more than a year. Other links just do not work. Others are clearly not updated, significantly some year reports, which, in some cases, were last updated in 1999.

Table I shows the percentages of the different types of documents present in 2001 and 2002, according to the number of times they appeared on the pages. The most apparent one is the sharp increase experienced by the presence of the Suggestions link, which doubled in a year. This means that there is a growing number of university libraries that develop initiatives to be more "customer focused". Keeping in touch with customers by these means allows to monitor on an ongoing basis how they perceive the services, and use this information in a positive way to develop, render, and improve them.

Throughout the year some documents have disappeared from, and others have appeared on, the Web pages. Among the former, the most representative ones are evaluation reports, procedure handbooks, duplicate bulletins, and data about co-operation, as well as the already mentioned year reports and statistics. The most interesting new comers are: Collection Management Program, Jobs List, Sponsorship information, Training Plan, and Budget. The document type whose appearance oscillates the most is the announcement of grants to work in the library, as this is subject to the staff needs and time needed to apply for the grants.

\section{Analysis of management information}

After analysing the management information available in the SUL Web pages, we draw the following conclusions.

(1) In general terms, this information is scanty. Documents of great interest, such as strategic plans allowing to know the main action lines of the library within the 
framework of the university, are missing. Collection development policies or programs are also missing. Catalan libraries are the ones providing the most information about their management.

(2) Lack of a university-library common policy that determines the information to be published on the Web site and, more specifically, the library's management information, as this differs considerably from one to the next. The information that each library provides in this respect is a manifestation of its interest in showing to the university community its management transparency, in line with its university. At the level of the University Libraries Network, there is still no joint action in this respect, according to the REBIUN Strategic Plan approved in May 2002, which covers from 2003 to 2006.

(3) This information is grouped in many different ways. In some Web sites it is necessary to improve the consistency and organisation of the contents. We think all of it should be included in one information block, which, following the Anglo-Saxon models already used by some of the libraries analysed above, could be called: "The library", "About the library", or "Library information". Within this information block, some documents are particularly interesting:

- mission (including vision and values),

- organisation chart;

- rules (including the regulations and any other guidelines for the use of the service);

- service chart;

- reports (including the annual report and the evaluation reports);

- co-operation;

- strategic plan;

- projects;

- statistics;

- scoreboard (or Indicators used in the evaluation of the service); and

- collection development policy or program.

(4) We stress the efforts initiated by some libraries to evaluate the quality of their services. This is a good indication that they are attentive to the needs and demands of their users and try and obtain data and criteria that will allow the library to keep up to date and adapt to the changing needs. On the other hand, the evaluation reports on this issue are the best source of information about the management of the library, as they allow to see the library's situation and evolution, as well as its priorities for the near future.

(5) The number of documents about their own management that libraries make available on their Web pages grows significantly day by day, and therefore the differences between libraries in this respect decrease. Despite this growth and with some interesting exceptions that show how some libraries are managed professionally, in general information is still scanty and it is not possible to do an overall assessment of their management, as there are not enough highly significant documents such as year reports or plans.

\section{Conclusions}

University libraries are starting to offer management information about themselves to their users through their Web site. Not only does this inform their customers, but it also contributes to the image of the library.

This paper has discussed a study carried out to ascertain the many types of management-related documents that SULs provide on their Web sites. The paper has given details on the structure, contents and location of the Web pages and has provided an analysis on the management information provided by the SULs. It is concluded that information is scanty in many cases - often resulting from a lack of a suitable information policy for determining what is published on the Web - although libraries are beginning to evaluate the quality of their services.

\section{Notes}

1 Available at: www.csic.es/cbic/webuni.htm

2 Available at: www.uma.es/rebiun/ informeEstadistico.html

3 Available at: www.igsap.map.es/cia/cartas/ rd1259-99.htm

\section{References}

Borrego, A. (2000), "Las bibliotecas universitarias castellanoleonesas vistas a través de sus páginas Web", [Castilla and León university libraries seen through their Web pages], III Jornadas de bibliotecas universitarias de Castilla y León. 16-17 November 
2000, Burgos, available at: www.ubu.es/biblioteca/ bucle/11.htm (accessed 21 July 2001).

Cohen, L.B. and Still, J.M. (1999), "A comparison of research university and two-year college library Web sites: content, functionality and form", College and Research Libraries, Vol. 60 No. 3, pp. 275-89.

Corrall, S. (2000), Strategic Management of Information Services: A Planning Handbook, ASLIB, London.

Herrera Morillas, J.L., Fernández Falero, M.R. and Peral Pacheco, D. (2001), "Los reglamentos y normativas de bibliotecas universitarias españolas disponibles en páginas Web", [Rules and regulations of Spanish university libraries available in Web pages], Revista General de Información y Documentación, Vol. 11 No. 2, pp. 231-57.

Kaplan, R.S. and Norton, D.P. (2000), Cuadro de Mando Integral [The Balanced Scorecard], Gestión 2000, Barcelona.

\section{Further reading}

Amat, O. and Soldevilla, P. (2002), El cuadro de mando integral en el mundo universitario: el caso de la Universidad Pompeu Fabra, available at: www. santcugatobert.net/Jornada/art-oriol-amat.pdf (accessed 14 October 2002).

Anglada, L. (1999), "L'elaboració d'una guia per I'avaluació dels serveis bibliotecaris de les universitats de Catalunya", [Creation of an evaluation guide for the library services of Catalonian universities], 7es. Jornades Catalanes de Documentació, Colegi Oficial de BibliotecarisDocumentalistes de Catalunya, Barcelona, pp. 31-7.

Bibliotecas universitarias: Recomendaciones sobre su reglamentación (1987), [University libraries: Recommendations on their regulations], Ministerio de Cultura, Madrid.

Guía d'Avaluació dels Serveis Bibliotecaris (2000), [Evaluation Guide of Library Services], available at: www.bib.ub.es/bub/avalua/avaluaci.htm (accessed 19 July 2001).

REBIUN (n.d.), Plan estratégico 2003-2006 [REBIUN Strategic Plan], available at: www.crue.org/rebiun/ PlanEstrategico.pdf (accessed 14 September 2002).

\section{Appendix. Some representative examples of the types of documents being analysed (were available at January 2003)}

\section{Self-evaluation reports}

www.bib.uab.es/avaluacio/autoinforme.htm http://biblioteca.unirioja.es/biblio/bur/ burautoev.html http://librivision.uniovi.es/web/ eval_prim_resul.html http://biblioteca.ulpgc.es/Publicac/informes. htm

Final-reports

www.upf.es/bib/coneixer/avalua/inforfin.htm http://biblioteca.unirioja.es/biblio/bur/ burdoces.html www.bib.uab.es/avaluacio/infofinal.pdf www.uib.es/servei/biblioteca/info/avaluacio/ index.html

Collection's management policy www.uc3m.es/biblioteca/ADQ/ gestion-coleccion.html www.ual.es/Universidad/Biblioteca/ adquisiciones/procrev.htm Improvement groups www.blues.uab.es/spada/millora/millora.htm Plans

Environmental plan: http://escher.upc.es/sts/ pma.htm

Strategics Plans: http://bibliotecnica.upc.es/ Pla_estrategic/Paideia.pdf www.uc3m.es/uc3m/serv/BIB/RE/guia/ planactuacion $1 . h \mathrm{hm}$ Balanced scoreboard or indicators www.upf.es/bib/coneixer/qci/qciind.htm fobs list www.unirioja.es/Personal/RPT/Biblioteca.html Staff training plan www.uib.es/servei/biblioteca/serveis/ formacio/pla_formacio.html

\section{Biography}

Ana R. Pacios is lecturer at the Library Science and Documentation Department of Carlos III University, Madrid, teaching library management related subjects in courses leading to a Diploma, Degree or PhD in Library Science and Documentation. Her main line of research is the management functions and techniques as applied to libraries. She is the author of various works published in both national and international library magazines. A member of the University Library Commission, Ana has co-ordinated one of the working groups created to carry out the evaluation of the Commission. She can be contacted at: Ana R. Pacios, Lecturer of Library Management, Library Science and Documentation Department, Carlos III University, Madrid, C/Madrid 126,128-28903 GETAFE, Spain. Tel: 91-6249225; E-mail:

areyes@bib.uc3m.es 